\title{
The influence of corpulence on the mechanical properties of the human heel fat pad in elderly
}

\author{
Frank Lindner, Günther Schlee, Thomas L Milani \\ From 3rd Congress of the International Foot and Ankle Biomechanics Community \\ Sydney, Australia. 11-13 April 2012
}

\section{Background}

The human heel fat pad (HFP) is an effective shock absorber [1]. A remodelling of body fat begins from the fifth decade of the human life. Diet may negatively influence this distribution and consequently lead to corpulence in elderly persons. Alcantara and colleges reported that fat content in the HFP increases with obesity [2]. Hence, the purpose of this investigation was to deter- mine the effect of corpulence on the mechanical properties of the HFP in elderly. We hypothesized, that corpulence alters mechanical properties of the HFP compared to normal weighted elderly persons.

\section{Materials and methods}

Twenty-three healthy elderly corpulent (age $61 \pm 6 \mathrm{yrs}$, height $171 \pm 8 \mathrm{~cm}$, BMI $28 \pm 2$, weight $82 \pm 7 \mathrm{~kg}$ ) and

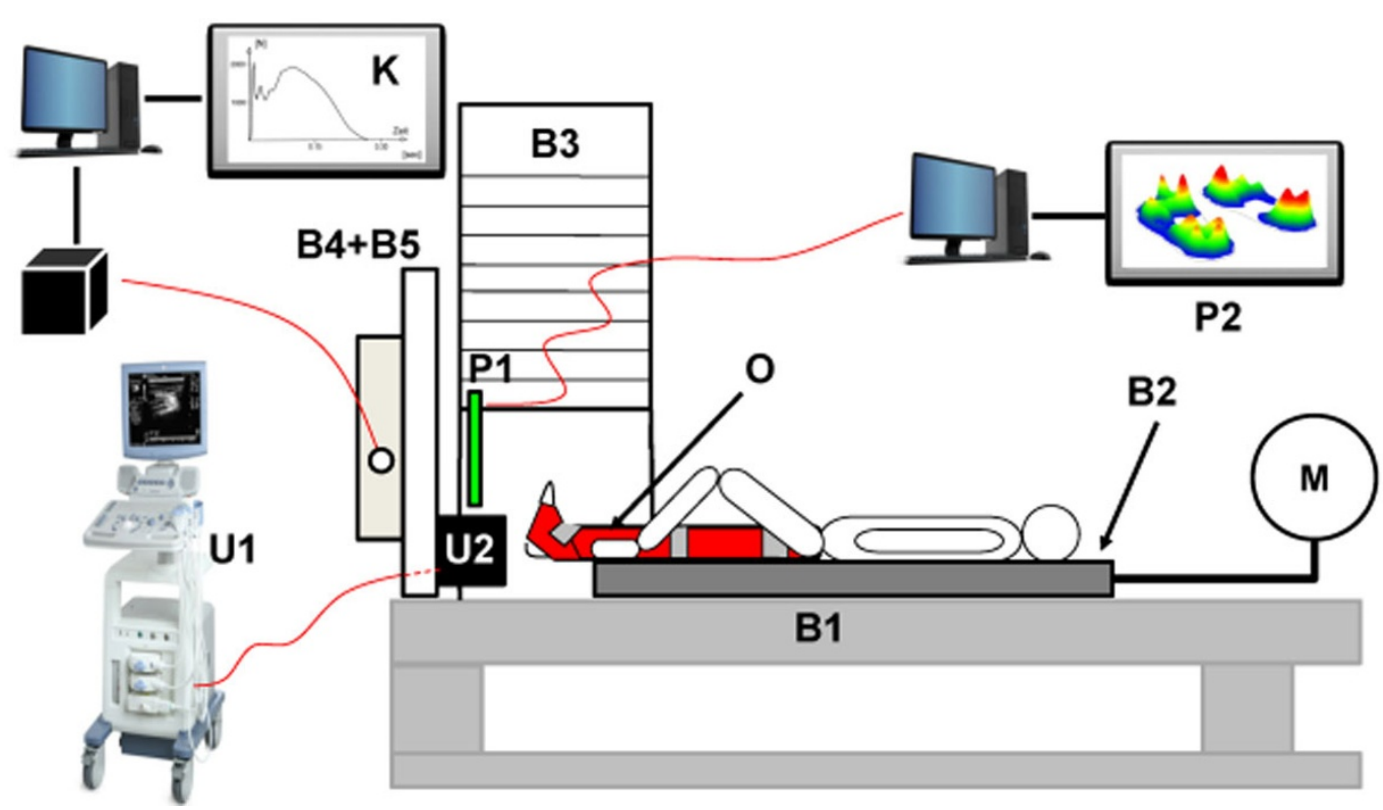

Figure 1 shows the loading device (measurement accuracy of the system is $0.09 \mathrm{~mm}$ and $18 \mathrm{kPa}$ ). Details on design of the loading device: $\mathbf{B} 1$ foundation, B2 carriage, B3 tower of weights, B4+B5 separated footrest with integrated GRF-platform (1000 Hz) to measure Vertical GRF, M microprocessor controlled step motor for the velocity controller of the carriage, $\mathbf{O}$ leg brace; $\mathbf{P} \mathbf{1 + P 2}$ emed pedography platform (resolution 2 sensors $/ \mathrm{cm}^{2}$, frequency $50 \mathrm{~Hz}$ ), U1 Ultrasound device (axial resolution $0.07 \mathrm{~mm}$ ), U2 fixture with integrated ultrasound transducer

\footnotetext{
* Correspondence: Frank.Lindner@hsw.tu-chemnitz.de

Institute of Sport Science, Human Locomotion, Chemnitz University of

Technology, Chemnitz, Free State of Saxony, 09107, Germany
} 
nineteen non-corpulent men and women (age $61 \pm$ 7 yrs, height $168 \pm 8 \mathrm{~cm}$, BMI $23 \pm 1$, weight $65 \pm 7 \mathrm{~kg}$ ) took part in the experiment. A loading device was used for in vivo testing of the HFP (Figure 1). Parameters were measured under two different impact velocities (low $2 \mathrm{~mm} / \mathrm{s}$, fast $10 \mathrm{~mm} / \mathrm{s}$ ). Several mechanical variables (unloaded and loaded HFP thickness, stiffness S, elasticity $\varepsilon$ ) were calculated.

\section{Results}

Thickness variables of corpulent subjects were significantly higher compared to the non-corpulent. The stiffness was found to have a nonlinear behaviour in which corpulent subjects show lower stiffness in the final stage. There was no significant difference in $\varepsilon$.

\section{Conclusions}

Increased HFP thickness is an adaption process to increased body weight, suggesting that an accumulation of fat cells with good blood supply at micro chamber structure may have occurred. This process protects the macro chamber structure of the HFP against overload that is transferred by micro chambers. Therefore, the micro chamber structure of corpulent elderly may be mechanically more sensitive and damageable than in non-corpulent subjects.

Published: 10 April 2012

\section{References}

1. Robbins SE, Gouw GJ, Hanna AM: Running-related injury prevention through innate impact moderating behavior. Med Sci Sport Exer 1989, 21:130-139.

2. Alcántara E, Forner A, Ferrús E, García AC, Ramiro J: Influence of age, gender, and obesity on the mechanical properties of the heel pad under walking impact conditions. J Appl Biomech 2002, 18:335-345.

doi:10.1186/1757-1146-5-S1-P20

Cite this article as: Lindner et al:: The influence of corpulence on the mechanical properties of the human heel fat pad in elderly. Journal of Foot and Ankle Research 2012 5(Suppl 1):P20.
Submit your next manuscript to BioMed Central and take full advantage of:

- Convenient online submission

- Thorough peer review

- No space constraints or color figure charges

- Immediate publication on acceptance

- Inclusion in PubMed, CAS, Scopus and Google Scholar

- Research which is freely available for redistribution

Submit your manuscript at www.biomedcentral.com/submit
C BioMed Central 